\title{
Targeting Notch3 in Hepatocellular Carcinoma: Molecular Mechanisms and Therapeutic Perspectives
}

\author{
Catia Giovannini ${ }^{1,2, *}$, Luigi Bolondi ${ }^{1,2}$ and Laura Gramantieri ${ }^{1}$ \\ 1 Centre for Applied Biomedical Research (CRBA), S. Orsola-Malpighi University Hospital, \\ 40138 Bologna, Italy; luigi.bolondi@unibo.it (L.B.); laura.gramantieri@aosp.bo.it (L.G.) \\ 2 Department of Medical and Surgical Sciences, University of Bologna, 40138 Bologna, Italy \\ * Correspondence: catia.giovannini4@unibo.it; Tel.: +39-051-214-4903; Fax: +39-051-636-3902 \\ Academic Editor: Akihiro Tamori \\ Received: 29 September 2016; Accepted: 16 December 2016; Published: 28 December 2016
}

\begin{abstract}
The Notch signaling pathway is a very conserved system that controls embryonic cell fate decisions and the maintenance of adult stem cells through cell to cell communication. Accumulating evidence support the relevance of Notch signaling in different human diseases and it is one of the most commonly activated signaling pathways in cancer. This review focuses mainly on the role of Notch3 signaling in hepatocellular carcinoma and its potential therapeutic applications against this malignancy. In this regard, the crosstalk between Notch and p53 may play an important role.
\end{abstract}

Keywords: Notch; p53; hepatocellular carcinoma (HCC)

\section{Notch Signaling}

The Notch signaling system is crucial for normal development and cell specification in many organs, and it is highly evolutionarily conserved. Four Notch receptors (Notch1, Notch2, Notch3, and Notch4) have been identified in humans and are essential for normal development, with mutations being responsible for CADASIL (Cerebral Autosomal Dominant Arteriopathy with Subcortical Infarcts and Leukoencephalopathy) and Alagille syndromes [1,2]. Notch receptors are heterodimers of two subunits comprising an extracellular domain, rich in EGF repeats, a transmembrane domain and an intracellular domain. The subunits are held together by non-covalent interactions [3].

Notch receptors transduce signals by interacting with transmembrane ligands of the Delta-like (DLL1, 3, and 4) and Jagged (Jagged1 and 2) protein family on neighboring cells [4]. Activating interactions between the receptors and the ligands depend on the interaction of the EGF (Epidermal Growth Factor)-like repeats of the Notch receptors with the DSL domain of the ligands [5]. Ligand binding initiates a series of cleavage events. The first one results in the shedding of the extracellular domain and exposure of a metalloprotease site (S2) which becomes susceptible by the proteases ADAM10 or by TACE (Tumour necrosis factor (TNF)- $\alpha$ converting enzyme). Following this cleavage the resulting Notch fragment, called NEXT (Notch extracellular truncation), is cleaved by $\gamma$-secretase and NICD (Notch intracellular domain) is released in the cytoplasm [6]. The activation of Notch largely depends on $\gamma$-secretase activity and GSIs (Gamma Secretase Inhibitors) are under evaluation in clinical trials in several human diseases $[7,8]$.

NICD is then translocated into the nucleus where it forms a transcriptional complex with the DNA binding protein CSL (CBF1 Suppressor of Hairless Lag1; also called RBP-Jk), Mastermind (Maml), and transcriptional co-activators to drive the expression of Notch target genes (Figure 1). The HES (hairy / enhancer of split) and HERP (HES-related repressor protein) families of transcriptional repressors are the most known targets of Notch signaling [9]. Despite the relative simplicity of the Notch signaling pathway it can generate diverse signaling outputs, as evidenced by profoundly distinct 
transcriptomic responses in different cell types. Moreover, the inhibition of different Notch receptors has different effects in the liver, underscoring their distinct roles [10,11].

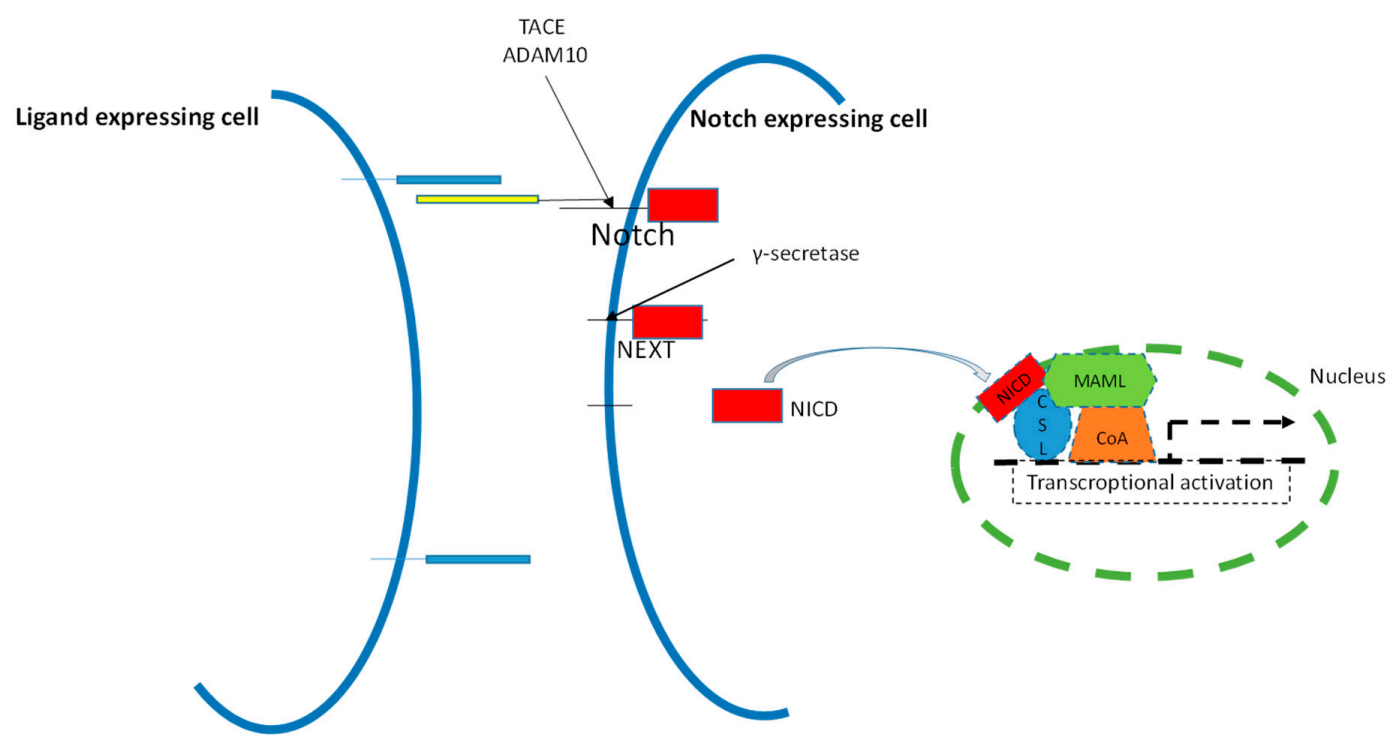

Figure 1. Canonical Notch signaling pathway. Notch receptors are heterodimeric cell membrane proteins containing a $200-\mathrm{kDa}$ extracellular subunit and a $120-\mathrm{kDa}$ fragment that includes a transmembrane and an intracellular domain. Notch receptors are activated by trans-membrane ligands expressed on the surface of neighboring cells. Upon ligand binding, two proteolytic cleavages occur. The first cleavage takes place 12 amino acids outside the trans-membrane domain by metalloproteinase TACE/ADAM10. The resultant Notch COOH-terminal fragment, called NEXT (Notch extracellular truncation), is required for the second cleavage performed by $\gamma$-secretase within the trans-membrane region. This last proteolytical event releases a $65-95 \mathrm{kDa}$ Notch intracellular domain (NICD) from the $120-\mathrm{kDa}$ fragment. NICD molecular weight is highly dependent on the Notch receptor that is cleaved. NICD translocates to the nucleus, interacts with DNA binding proteins and transactivates target genes.

\section{Notch Pathway in Cancer}

During normal development, several mechanisms are used to regulate Notch activity, the best studied of these being lateral contact with neighboring cells, required for correct cell positioning, cell fate, and survival [12]. The Notch family of transcription factors plays critical roles for the efficiency of these fundamental cellular processes in a wide range of tissues. Thus, it is no surprise that the aberrant gain or loss of Notch signaling components has been associated with multiple human disorders including cancer $[13,14]$. Perturbations of Notch signaling pathway may be caused by an altered expression of Notch receptors or by deregulated expression of Notch ligands. Herein, we focused on Notch receptors whose dysregulation has been found in a variety of human malignancies where they are involved in either survival or death pathways, growth arrest, or proliferation and differentiation [15] (Table 1). The cellular outcome of this aberrant Notch signaling is highly dependent on the context, on the interactions with the tumor microenvironment and crosstalk with other signaling pathways. 
Table 1. Oncogenic and tumor-suppressive role of notch signaling in human cancers.

\begin{tabular}{lccc}
\hline \multicolumn{1}{c}{ Tumor Type } & Function & Notch Receptor Involved & References \\
\hline T-cell acute lymphoblastic leukemia (T-ALL) & Oncogenic & Notch1 & Weng et al. 2004 [16] \\
\hline Breast Cancer & Oncogenic & $\begin{array}{c}\text { Notch1; Notch4; } \\
\text { Notch3; Notch2 }\end{array}$ & $\begin{array}{c}\text { Klinakis et al. 2006 [17]; } \\
\text { Gallhan et al. 1997 [18]; } \\
\text { Yamaguchi et al. 2008 [19]; } \\
\text { Fu et al 2010 [20]; } \\
\text { Florena et al. 2007 [21] }\end{array}$ \\
\hline Acute myeloid leukemia (AML) & Oncogenic & Notch1 & Xu et al. 2011 [22] \\
\hline Tumor of the skin & Tumor-Suppressor & Notch1 & Nicolas et al. 2003 [23] \\
\hline Forebrain Tumor & Tumor-Suppressor & Notch1 and Notch2 & Giachino et al. 2015 [24] \\
\hline Colorectal Cancer (CRC) & Oncogenic & Notch1 & Babaei-Jadidi et al. 2011 [25] \\
\hline Squamous cell carcinomas & Tumor-Suppressor & Notch1 & Zhang et al. 2016 [26] \\
\hline Human non-small cell lung cancer (NSCLC) & Oncogenic & Notch1; Notch3 & $\begin{array}{c}\text { Westhoff et al. 2009 [27]; } \\
\text { Konishi et al 2010 [28] }\end{array}$ \\
\hline Pancreatic Cancer & Oncogenic & Notch1 & Wang et al 2006 [29] \\
\hline Ovarian Cancer & Oncogenic & Notch3 & Park et al. 2006 [30] \\
\hline Hepatocellular Carcinoma & Oncogenic & Notch1; Notch3; Notch2 & $\begin{array}{c}\text { Giovannini et al. 2016 [31]; } \\
\text { Giovannini et al 2013 [32] }\end{array}$ \\
\hline Cholangiocarcinoma; Prostate Cancer & Oncogenic & Notch1 & Huntzicker et al. 2015 [11]; \\
\hline Bladder Cancer & Oncogenic & Notch2 & Hayashi et al. 2016 [34] \\
\hline Gastric Cancer & Oncogenic & Notch2 & Tseng et al. 2012 [35] \\
\hline Salivary Adenoid Cystic Carcinoma & Oncogenic & Notch2 & Qu et al. 2016 [36] \\
\hline
\end{tabular}

\section{Notch as an Oncoprotein}

The first reported Notch1 alteration was the identification of a chromosome translocation by fusing T-cell receptor- $\beta$ to ICN1 in T-cell acute lymphoblastic leukemia (T-ALL) resulting in constitutive active Notch1 [37]. Then, Aster and Weng reported activated Notch1 mutations in more than $50 \%$ of pediatric patients with T-ALL [16,37-40]. Other studies assessed the prognostic implication of Notch in other leukemia subtypes [22]. Notch1 and Notch2 fusion transcript, retaining the exons that encode the Notch intracellular domain (NICD,) was subsequently described in breast cancer [41,42]. Breast cancer was the first solid tumor in which Notch derangement was molecularly implicated. In line with this evidence, both Notch1 and Notch4 are involved in driving mammary tumorigenesis in mice $[17,18]$. Moreover, Notch2 may promote the development of estrogen receptor (ER)+ luminal tumors [20]. A role of Notch2 and Akt in breast cancer progression was also supposed [21]. An oncogenic role of Notch2 was described in salivary adenoid cystic carcinoma [36], in bladder cancer [34], and in gastric cancer [35]. Induction of Notch signaling was observed in primary human non-small cell lung cancer (NSCLC) [27]. Notch1 down-regulation inhibits invasion and proliferation of pancreatic cancer cells [29,43]. Notch signaling is overexpressed or constitutively activated in colorectal cancer (CRC) in part because of mutations in regulators of Notch signaling, including FBXW7 [25,44,45]. More specifically, FBXW7 (SEL-10) functions as an E3 ligase. It binds to the intracellular region of Notch and promotes its ubiquitination and degradation [46-48]. Notch3 signaling plays an important role in the proliferation of ErbB2-negative breast tumor cells and its targeted suppression may be a promising strategy for this cancer treatment [19]. Notch3 appears to be a key player in NSCLC, indeed, its suppression results in loss of the malignant phenotype both in vitro and in vivo models [28]. Notch3 amplification was observed in ovarian cancer and is required for tumor proliferation [30]. Aberrant Notch signaling has been found in many other cancers [15,49].

\section{Notch as a Tumor Suppressor}

In some cancers, such as skin squamous cell carcinoma, Notch signaling promotes differentiation and growth arrest [23]. Recently Notch1 mutations have been associated with favorable long-term 
prognosis in pediatric T-ALL [50]. Giachino et al. identified a tumor suppression function for Notch in forebrain tumor subtype [24]. It has also been reported that Notch may function as tumor suppressor in squamous cell carcinomas (SCCs) of cutaneous, lung, head and neck and esophageal where Notch1 mutations are associated with Notch1 loss of function [26]. The mechanisms by which the Notch pathway can exert tumor promoting or suppressive activity in different cell types are not completely understood and are probably dependent on the microenvironment [51]. It is conceivable that the role of Notch receptors in cancer parallels the role of Notch in tissue development. There are distinct modes of aberrant regulation of the Notch pathway including epigenetic regulation, posttranslational modification, and deregulated expression of Notch ligands [52-55]. However, the lack of widespread mutational activation in solid tumors leaves doubts about the oncogenic role of Notch [56].

\section{Notch in Human Hepatocellular Carcinoma}

Hepatocellular carcinoma (HCC) accounts for $80 \%-90 \%$ of liver cancers and is the third leading cause of cancer mortality worldwide moreover, HCC is increasing throughout the world [57]. The primary risk factor for HCC is represented by liver cirrhosis, as it is present in the majority of HCC patients [58,59]. Although the majority of cirrhotic patients have a history of viral hepatitis [58,60], metabolic disorders are emerging as etiologic factors for HCC too. Roughly two-thirds of total cirrhotic patients with a viral background are attributed to hepatitis B viral (HBV) infections, while the remaining third are affected by hepatitis C HCV) $[59,61]$. There is compelling evidence that the Notch signaling pathway may play an important role in HCC. Most of the studies have focused on Notch1, whose role is still ambiguous in terms of anti-tumoral effects following its inhibition [62]. Notch1 increased during the hepatocarcinogenesis process induced by the methyl-deficient diet in the rat liver [63]. Moreover, Notch1 signaling promotes liver carcinogenesis in animal models [31,64]. On the other hand, Huntzicker and coauthors described how Notch1 inhibition altered the proportion of tumor types, reducing HCC-like tumors and increasing cholangiocarcinoma-like tumors [11]. Understanding the control of stem cell proliferation may help us understand the molecular events sustaining hepatocarcinogenesis [65], raising the possibility that Notch1 activity is highly context-dependent. Regarding Notch2 and Notch4, there are studies supporting their role in tumor aggressiveness and metastasis [66-69]. Specifically, Notch2 signaling was associated with aggressiveness in HCC [66], and its oncogenic potential in the liver was demonstrated in mice whether constitutive Notch2 expression contributes to HCC formation or not [70]. Notch2 inhibition represents a therapeutic option in the treatment of liver cancer [11]. Both Notch2 and Notch4 receptors were found to be involved in the proliferation of hepatoblasts [71]. Notch3 is the only Notch receptor expressed in liver tissue during the middle embryonic stage. Notch3 expression is stronger in the differentiation of stem/progenitor cells (FLSPCs) compared with the adult liver and with the mature rat liver cell line BRL (Buffalo rat liver), respectively. More specifically, as the differentiation of FLSPCs progresses towards hepatocytes, Notch3 protein expression is gradually downregulated, together with the downregulation of other stem cell markers [72]. Conversely, Notch3 results are crucial for bile duct development [73], and its expression persists on the bile duct epithelium in liver tissue [74]. These findings suggest that Notch 3 is a potential marker of FLSPCs and regulates the differentiation of FLSPCs into hepatocytes; thus, Notch3 might deserve attention as a possible target driving the use of FLSPCs in the treatment of ESLD (end-stage liver disease). The apparent role of Notch3 in differentiation raises speculations that it might be involved in HCC development. In line with these observations, we reported Notch3 abnormal accumulation in 78\% of early HCCs [69]. Bile ducts surrounding HCC nodules stained positive for Notch3 in nearly all cases, raising the question as to whether Notch inhibition might contribute to cholestasis.

Venous endothelia inside the HCC nodule and the stromal cells surrounding neoplastic nodules were positive, while arteriosus endothelia in liver tissue adjacent to HCC nodules were negative. In chronic hepatitis and cirrhosis, Notch3 expression localized to the small- and medium-sized bile ducts [69]. Although functional implications cannot be proven from a descriptive study, the results 
suggest a possible role of Notch3 in HCC development. In line with these observations, it was reported that Notch3 gene is the most highly upregulated Notch pathway member in HCC tissues compared with normal liver tissue [75]. Although a study conducted in Asiatic patients showed no difference in Notch3 expression between hepatocellular carcinoma and adjacent non-tumor liver cells [76], suggesting that environmental factors are also involved in HCC development, Notch3 should be considered a specific therapeutic target for HCC. Moreover, it is becoming increasingly clear that the effect of signaling proteins is determined not only by the biochemical properties but also by the cellular context in which the protein operates. This also applies to Notch signaling. It is conceivable that both the tumor-suppressive and the oncogenic properties of Notch3 take place at the same time, and the outcome relies upon the cellular context, as described below.

\section{Notch 3 as a Mediator of Chemotherapeutic Resistance in HCC}

There is mounting evidence that the Notch pathway contributes to chemoresistance in different human cancers. A recent study on ovarian cancer demonstrated that Notch3 increased resistance to platinum-based chemotherapy and the cancer stem cell population within the tumor [77]. A comparable study in prostate cancer demonstrated that knocking down Notch1 sensitized the cells to treatment with docetaxel [33]. Additional work in glioma reported that Notch promotes both chemoresistance and radioresistance [78]. In HCC models, Notch3 ablation exacerbates the apoptotic response to doxorubicin, which is mostly dependent on p53. [79]. Moreover, we demonstrated that Notch3 inhibition enhances the effect of sorafenib in HCC, in vitro and in vivo [32]. Importantly the effects of Notch 3 depletion in sorafenib response are mediated by p 21 and pGSK $3 \beta^{\text {Ser9 }}$ and, probably, by neo-angiogenesis inhibition [32]. Notch3 participates in the process of HCC development in rats treated with diethylinitrosamine, suggesting an active role of Notch3 during carcinogenesis. This observation implies that pharmacological inhibition of Notch3 might reduce HCC development and recurrence after treatments, providing a strong basis for the use of Notch3 inhibition in combination with traditional therapeutic options for the treatment of HCC. $\gamma$-secretase inhibitors (GSI) are today evaluated as promising inhibitors of Notch signaling in neoplastic disease [80,81]. RO49229097 is a GSI that showed decreased NICD expression in vitro and in vivo and a significantly inhibition of tumor growth [82]. PF-03084014 is a GSI that has been tested in combination with different treatments in breast, pancreatic, and colorectal cancer [83-85], and clinical trials are still ongoing. Unfortunately GSIs are not highly specific [86], have a marked effect on lymphocyte development, and induce changes in gastrointestinal tract [87]. The selective targeting of Notch3 should be preferred for HCC therapy to avoid additional unknown effects to non-neoplastic cirrhotic liver cells that stain negative for Notch3 and positive for others Notch receptors such as Notch4 [69]. Moreover, Pan-Notch inhibitors for HCC could result in stimulating Notch pro-survival activity if not combined with conventional treatment. Indeed, it has been shown that Notch3 inhibition induces a senescent state in HCC cells that depends on p57 accumulation [88].

Senescence inhibits the growth of many tumors including epithelial tumors of the colon, head and neck, and thyroid [89-91]. On the other hand, senescent cells in the tumor bulk are important biological factors that might have prognostic implications for the disease outcome. Senescent tumor cells might secrete factors with mitogenic, antiapoptotic, and pro-angiogenic activities [92] leading to a worse prognosis in HCC. In line with the latter, higher p57 protein levels were associated with reduced time to recurrence (TTR) after curative resection [88]. The above considerations recommend caution in suggesting treatments with single general inhibitors of Notch activity (such as $\gamma$-secretase inhibitors) for HCC. Approaches that are more promising include selective inhibitors that can suppress the Notch3 pro-survival functions. Alternatively, a combination therapy based on Notch3 inhibitors in conjunction with chemotherapeutic compounds with pro-apoptotic activity should be considered, as we previously showed [32,79]. Moreover, a combination of Notch3 inhibitors with standard therapy might be a good strategy in order to reduce the dosages of the therapeutic agents administrated locally or systemically, limiting side effects and toxicity. 


\section{Notch Crosstalk}

Increasing evidence demonstrates that Notch cross-talks with several conserved pathways mainly involved in stem-cell self-renewal, differentiation, and tumorigenesis (Figure 2). It is also believed that the crosstalk between Notch and other signaling pathways plays an important role in tumor aggressiveness. The manner in which the Notch signals crosstalk with the signals from other pathways is one potential way to affect Notch activity and may be context-dependent.

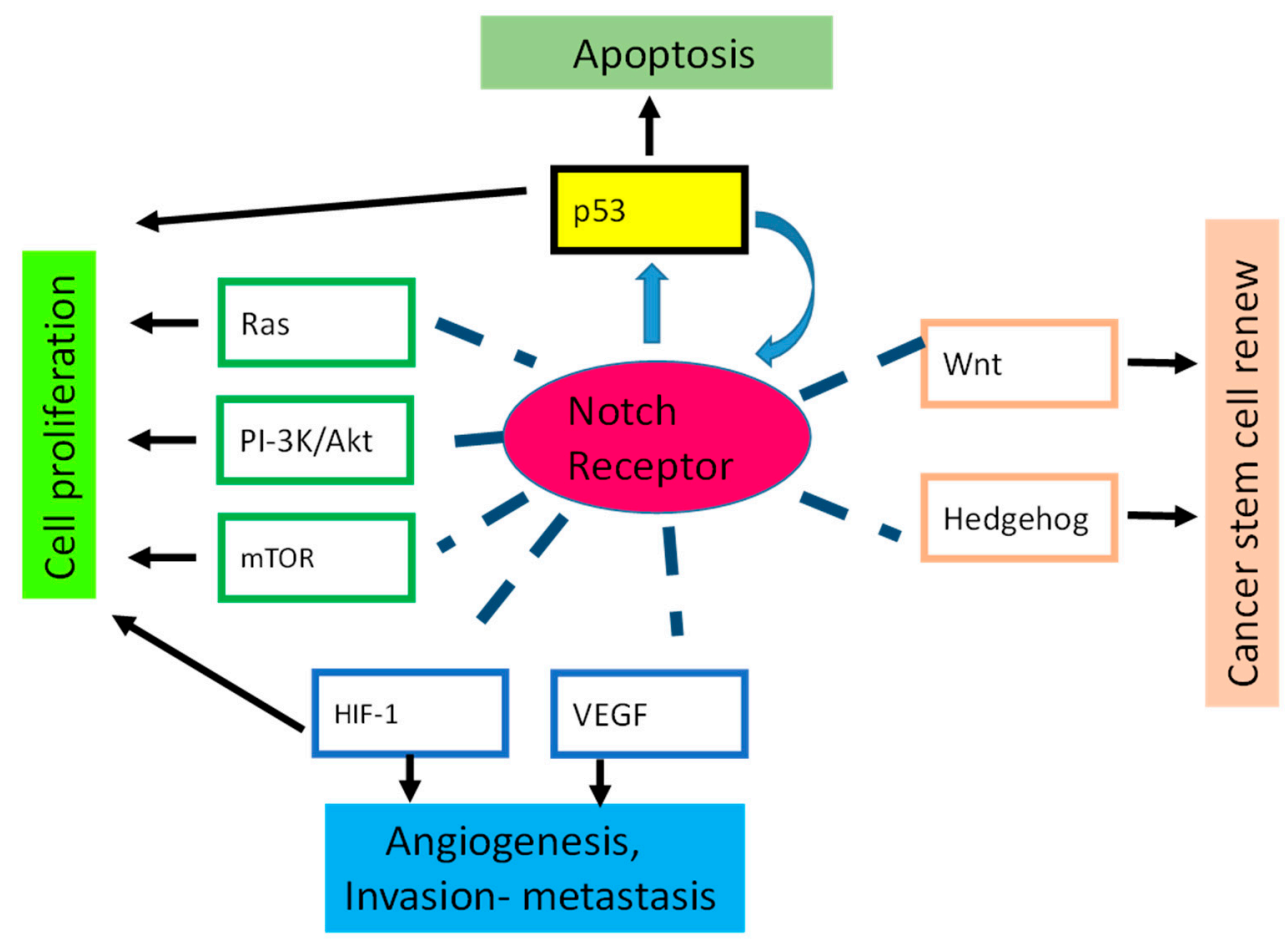

Figure 2. Notch crosstalk. The figure shows the major cellular pathways that interact with Notch signaling. VEGF: vascular endothelial growth factors.

Notch crosstalk with several conserved pathways including Hedgehog [93,94], Wnt and vascular endothelial growth factors (VEGF) $[95,96]$.

Hypoxia also maintains a stem-cell-like phenotype in colorectal cancer cells in a Notch-dependent manner [97]. Notch cross-talks with the PI3K pathway in breast cancer and is a positive regulator of the PI3K/AKT/mTOR pathway in T-ALL $[98,99]$. Notch signaling can interface with a large number of cancer-relevant pathways, thus Notch-pathway inhibitors will show optimal efficacy in combination regimens. In this context, Notch interaction with p53 in cancer deserves to be the subject of intensive study [100].

\section{8. p53 Is Regulated by Notch in Human Cancer}

The tumor suppressor protein p53 acts primarily as a transcription factor, inducing the expression of genes involved in different cellular functions [101]. The efficiency of p53 as a tumor suppressor reflects the alteration of the normal p53 pathway in most cancers, frequently reached by p53 mutations or deletions [102]. However, many other mechanisms involved in p53 regulation, including Notch signaling, have been described. In a mouse model of lymphomagenesis, Notch1 activation reduces p53 levels through increased MDM2 activity [103]. The Notch1/miR-151-5p axis contributed to the progression of gastric cancer cells through downregulation of p53 [104]. NICD-1 inhibits p53 by preventing its phosphorylations at Ser15, Ser20, and Ser392, as well as nuclear localization [105]. 
In hepatocellular carcinoma, Notch3 regulates p53 at a post-transcriptional level, controlling Cyclin G1 expression and the feed-forward circuit involving p53, miR-221, and MDM2 [106]. More in detail, the increase in p53 protein expression in Notch3-depleted cells is first mediated by a dramatic decrease of Cyclin G1. Then, p53 accumulation in Notch3-silenced cells triggers the upregulation of its known transcriptional target miR-221, leading to MDM2 reduction and thus to increased p53 stability. On the contrary, Notch1 activation upregulates p53 protein expression in HCC cells by inhibiting proteasome degradation [107].

RBP-Jkappa (CSL), an essential mediator of the Notch receptor signaling pathway, binds to the p53 promoter and represses p53 gene expression [108].

A study by Colaluca et al. shows that Numb, which is commonly associated with negative regulation of Notch proteins, plays an important role in the activation of p53 in breast cancer [109]. Loss of Numb is a critical step in the development of breast tumors, leading to the activation of Notch signaling and the inhibition of the p53 pathway [110].

It seems that Notch acts as a tumor suppressor in cells where Notch signaling supports p53 activation. In contrast, Notch frequently acts as an oncoprotein in cells where it suppresses p53 activity (Figure 3). Interestingly, in those tumors in which Notch signaling causes growth inhibition, p53 regulates Notch gene expression and not vice versa [111]. Indeed, p53 was found to specifically regulate Notch1 expression in cervical carcinoma cells [112]. Similar regulation of Notch1 expression by 553 occurs in lung and prostate cancer cells, where increased Notch signaling causes growth inhibition [112]. A probable p53 DNA-binding site about $3.7 \mathrm{~kb}$ upstream in the promoter region of the human Notch1 gene was identified [113]. Remarkably, p53 differentially regulated the expression of Notch family members: expression of Notch2 and Notch 4 was not induced by p53.

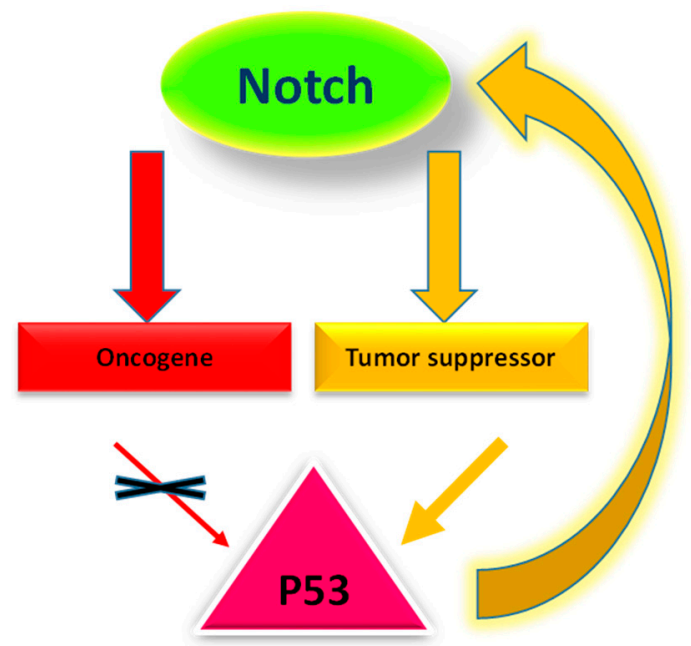

Figure 3. Crosstalk of Notch with p53. Notch acts as an oncogene in cells where it suppresses p53 activity whereas Notch acts as a tumor suppressor in cellular contexts where it supports p53 activation. p53 in turn regulates Notch expression in those tumors in which Notch exerts tumor suppressor activity (yellow representation).

\section{Conclusions}

The Notch signaling pathway is emerging more and more as a major player in cancer biology, including in hepatocellular carcinoma, where persistent Notch activation may lead to HCC proliferation, invasion, and resistance to conventional cancer therapy. In particular, Notch3 seems to be a relevant player in this neoplasia, and its specific inhibition may potentially be more effective than $\gamma$-secretase inhibitors that are not cell-selective and possess a considerable toxicity profile. To develop an effective therapeutic approach for HCC treatment, additional studies are required, also taking into account the important regulation mediated by Notch3 on p53. 
Acknowledgments: This work was supported by grants from Fondazione Cassa di Risparmio in Bologna (CARISBO) to Luigi Bolondi, Programma di Ricerca Regione-Università 2010-2012, Regione Emilia-Romagna, Bando "Ricerca Innovativa", to Luigi Bolondi and Laura Gramantieri, and from Fondazione del Monte di Bologna e Ravenna to Laura Gramantieri.

Author Contributions: Catia Giovannini wrote the manuscript; Luigi Bolondi and Laura Gramantieri revised the manuscript critically.

Conflicts of Interest: The authors declare no conflict of interest.

\section{References}

1. Spinner, N.B. CADASIL: Notch signaling defect or protein accumulation problem? J. Clin. Investig. 2000, 105, 561-562. [CrossRef] [PubMed]

2. Joutel, A.; Corpechot, C.; Ducros, A.; Vahedi, K.; Chabriat, H.; Mouton, P.; Alamowitch, S.; Domenga, V.; Cécillion, M.; Marechal, E.; et al. Notch3 mutations in CADASIL, a hereditary adult-onset condition causing stroke and dementia. Nature 1996, 383, 707-710. [CrossRef] [PubMed]

3. Lubman, O.Y.; Korolev, S.V.; Kopan, R. Anchoring notch genetics and biochemistry; structural analysis of the ankyrin domain sheds light on existing data. Mol. Cell 2004, 13, 619-626. [CrossRef]

4. Lissemore, J.L.; Starmer, W.T. Phylogenetic analysis of vertebrate and invertebrate Delta/Serrate/LAG-2 (DSL) proteins. Mol. Phylogenet. Evol. 1999, 11, 308-319. [CrossRef] [PubMed]

5. Miller, A.C.; Lyons, E.L.; Herman, T.G. cis-Inhibition of Notch by endogenous Delta biases the outcome of lateral inhibition. Curr. Biol. 2009, 19, 1378-1383. [CrossRef] [PubMed]

6. Mumm, J.S.; Kopan, R. Notch signaling: From the outside in. Dev. Biol. 2000, 228, 151-165. [CrossRef] [PubMed]

7. Tammam, J.; Ware, C.; Efferson, C.; O’Neil, J.; Rao, S.; Qu, X.; Gorenstein, J.; Angagaw, M.; Kim, H.; Kenific, C.; et al. Down-regulation of the Notch pathway mediated by a $\gamma$-secretase inhibitor induces anti-tumour effects in mouse models of T-cell leukaemia. Br. J. Pharmacol. 2009, 158, 1183-1195. [CrossRef] [PubMed]

8. Pandya, K.; Meeke, K.; Clementz, A.G.; Rogowski, A.; Roberts, J.; Miele, L.; Albain, K.S.; Osipo, C. Targeting both Notch and ErbB-2 signalling pathways is required for prevention of ErbB-2-positive breast tumour recurrence. Br. J. Cancer 2011, 105, 796-806. [CrossRef] [PubMed]

9. Jarriault, S.; Brou, C.; Logeat, F.; Schroeter, E.H.; Kopan, R.; Israel, A. Signalling downstream of activated mammalian Notch. Nature 1995, 377, 355-358. [CrossRef] [PubMed]

10. Gil-Garcia, B.; Baladron, V. The complex role of NOTCH receptors and their ligands in the development of hepatoblastoma, cholangiocarcinoma and hepatocellular carcinoma. Biol. Cell 2016, 108, 29-40. [CrossRef] [PubMed]

11. Huntzicker, E.G.; Hotzel, K.; Choy, L.; Che, L.; Ross, J.; Pau, G.; Sharma, N.; Siebel, C.W.; Chen, X.; French, D.M. Differential effects of targeting Notch receptors in a mouse model of liver cancer. Hepatology 2015, 61, 942-952. [CrossRef] [PubMed]

12. Hunter, G.L.; Hadjivasiliou, Z.; Bonin, H.; He, L.; Perrimon, N.; Charras, G.; Baum, B. Coordinated control of Notch/Delta signalling and cell cycle progression drives lateral inhibition-mediated tissue patterning. Development 2016, 143, 2305-2310. [CrossRef] [PubMed]

13. Lim, K.J.; Brandt, W.D.; Heth, J.A.; Muraszko, K.M.; Fan, X.; Bar, E.E.; Eberhart, C.G. Lateral inhibition of Notch signaling in neoplastic cells. Oncotarget 2015, 6, 1666-1677. [CrossRef] [PubMed]

14. Yamamoto, S.; Schulze, K.L.; Bellen, H.J. Introduction to Notch signaling. Methods Mol. Biol. 2014, 1187, 1-14. [PubMed]

15. Radtke, F.; Raj, K. The role of Notch in tumorigenesis: Oncogene or tumour suppressor? Nat. Rev. Cancer 2003, 3, 756-767. [CrossRef] [PubMed]

16. Weng, A.P.; Ferrando, A.A.; Lee, W.; Morris, J.P.; Silverman, L.B.; Sanchez-Irizarry, C.; Blacklow, S.C.; Look, A.T.; Aster, J.C. Activating mutations of Notch1 in human T cell acute lymphoblastic leukemia. Science 2004, 306, 269-271. [CrossRef] [PubMed]

17. Klinakis, A.; Szabolcs, M.; Politi, K.; Kiaris, H.; Artavanis-Tsakonas, S.; Efstratiadis, A. Myc is a Notch1 transcriptional target and a requisite for Notch1-induced mammary tumorigenesis in mice. Proc. Natl. Acad. Sci. USA 2006, 103, 9262-9267. [CrossRef] [PubMed] 
18. Gallahan, D.; Callahan, R. The mouse mammary tumor associated gene INT3 is a unique member of the NOTCH gene family (NOTCH4). Oncogene 1997, 14, 1883-1890. [CrossRef] [PubMed]

19. Yamaguchi, N.; Oyama, T.; Ito, E.; Satoh, H.; Azuma, S.; Hayashi, M.; Shimizu, K.; Honma, R.; Yanagisawa, Y.; Nishikawa, A.; et al. Notch3 signaling pathway plays crucial roles in the proliferation of ErbB2-negative human breast cancer cells. Cancer Res. 2008, 68, 1881-1888. [CrossRef] [PubMed]

20. Fu, Y.P.; Edvardsen, H.; Kaushiva, A.; Arhancet, J.P.; Howe, T.M.; Kohaar, I.; Porter-Gill, P.; Shah, A.; Landmark-Høyvik, H.; Fosså, S.D.; et al. Notch2 in breast cancer: Association of SNP rs11249433 with gene expression in ER-positive breast tumors without TP53 mutations. Mol. Cancer 2010, 9, 113. [CrossRef] [PubMed]

21. Florena, A.M.; Tripodo, C.; Guarnotta, C.; Ingrao, S.; Porcasi, R.; Martorana, A.; Lo Bosco, G.; Cabibi, D.; Franco, V. Associations between Notch-2, Akt-1 and HER2/neu expression in invasive human breast cancer: A tissue microarray immunophenotypic analysis on 98 patients. Pathobiology 2007, 74, 317-322. [CrossRef] [PubMed]

22. Xu, X.; Zhao, Y.; Xu, M.; Dai, Q.; Meng, W.; Yang, J.; Qin, R. Activation of Notch signal pathway is associated with a poorer prognosis in acute myeloid leukemia. Med. Oncol. 2011, 28 (Suppl. 1), S483-S489. [CrossRef] [PubMed]

23. Nicolas, M.; Wolfer, A.; Raj, K.; Kummer, J.A.; Mill, P.; van Noort, M.; Hui, C.C.; Clevers, H.; Dotto, G.P.; Radtke, F. Notch1 functions as a tumor suppressor in mouse skin. Nat. Genet. 2003, 33, 416-421. [CrossRef] [PubMed]

24. Giachino, C.; Boulay, J.L.; Ivanek, R.; Alvarado, A.; Tostado, C.; Lugert, S.; Tchorz, J.; Coban, M.; Mariani, L.; Bettler, B.; et al. A Tumor Suppressor Function for Notch Signaling in Forebrain Tumor Subtypes. Cancer Cell 2015, 28, 730-742. [CrossRef] [PubMed]

25. Babaei-Jadidi, R.; Li, N.; Saadeddin, A.; Spencer-Dene, B.; Jandke, A.; Muhammad, B.; Ibrahim, E.E.; Muraleedharan, R.; Abuzinadah, M.; Davis, H.; et al. FBXW7 influences murine intestinal homeostasis and cancer, targeting Notch, Jun, and DEK for degradation. J. Exp. Med. 2011, 208, 295-312. [CrossRef] [PubMed]

26. Zhang, M.; Biswas, S.; Qin, X.; Gong, W.; Deng, W.; Yu, H. Does Notch play a tumor suppressor role across diverse squamous cell carcinomas? Cancer Med. 2016, 5, 2048-2060. [CrossRef] [PubMed]

27. Westhoff, B.; Colaluca, I.N.; D’Ario, G.; Donzelli, M.; Tosoni, D.; Volorio, S.; Pelosi, G.; Spaggiari, L.; Mazzarol, G.; Viale, G.; et al. Alterations of the Notch pathway in lung cancer. Proc. Natl. Acad. Sci. USA 2009, 106, 22293-22298. [CrossRef] [PubMed]

28. Konishi, J.; Yi, F.; Chen, X.; Vo, H.; Carbone, D.P.; Dang, T.P. Notch3 cooperates with the EGFR pathway to modulate apoptosis through the induction of bim. Oncogene 2010, 29, 589-596. [CrossRef] [PubMed]

29. Wang, Z.; Banerjee, S.; Li, Y.; Rahman, K.M.; Zhang, Y.; Sarkar, F.H. Down-regulation of notch-1 inhibits invasion by inactivation of nuclear factor $-\kappa B$, vascular endothelial growth factor, and matrix metalloproteinase-9 in pancreatic cancer cells. Cancer Res. 2006, 66, 2778-2784. [CrossRef] [PubMed]

30. Park, J.T.; Li, M.; Nakayama, K.; Mao, T.L.; Davidson, B.; Zhang, Z.; Kurman, R.J.; Eberhart, C.G.; Shih, I.M.; Wang, T.L. Notch3 gene amplification in ovarian cancer. Cancer Res. 2006, 66, 6312-6318. [CrossRef] [PubMed]

31. Giovannini, C.; Minguzzi, M.; Genovese, F.; Baglioni, M.; Gualandi, A.; Ravaioli, M.; Milazzo, M.; Tavolari, S.; Bolondi, L.; Gramantieri, L. Molecular and proteomic insight into Notch1 characterization in hepatocellular carcinoma. Oncotarget 2016, 7, 39609-39626. [CrossRef] [PubMed]

32. Giovannini, C.; Baglioni, M.; Baron Toaldo, M.; Ventrucci, C.; D'Adamo, S.; Cipone, M.; Chieco, P.; Gramantieri, L.; Bolondi, L. Notch3 inhibition enhances sorafenib cytotoxic efficacy by promoting GSK3b phosphorylation and p21 down-regulation in hepatocellular carcinoma. Oncotarget 2013, 4, 1618-1631. [CrossRef] [PubMed]

33. Ye, Q.F.; Zhang, Y.C.; Peng, X.Q.; Long, Z.; Ming, Y.Z.; He, L.Y. siRNA-mediated silencing of Notch-1 enhances docetaxel induced mitotic arrest and apoptosis in prostate cancer cells. Asian Pac. J. Cancer Prev. 2012, 13, 2485-2489. [CrossRef] [PubMed]

34. Hayashi, T.; Gust, K.M.; Wyatt, A.W.; Goriki, A.; Jager, W.; Awrey, S.; Li, N.; Oo, H.Z.; Altamirano-Dimas, M.; Buttyan, R.; et al. Not all Notch Is Created Equal: The oncogenic role of Notch2 in bladder cancer and its implications for targeted therapy. Clin. Cancer Res. 2016, 22, 2981-2992. [CrossRef] [PubMed] 
35. Tseng, Y.C.; Tsai, Y.H.; Tseng, M.J.; Hsu, K.W.; Yang, M.C.; Huang, K.H.; Li, A.F.; Chi, C.W.; Hsieh, R.H.; $\mathrm{Ku}, \mathrm{H} . \mathrm{H}$.; et al. Notch2-induced COX-2 expression enhancing gastric cancer progression. Mol. Carcinog. 2012, 51, 939-951. [CrossRef] [PubMed]

36. Qu, J.; Song, M.; Xie, J.; Huang, X.Y.; Hu, X.M.; Gan, R.H.; Zhao, Y.; Lin, L.S.; Chen, J.; Lin, X.; et al. Notch2 signaling contributes to cell growth, invasion, and migration in salivary adenoid cystic carcinoma. Mol. Cell. Biochem. 2016, 411, 135-141. [CrossRef] [PubMed]

37. Ellisen, L.W.; Bird, J.; West, D.C.; Soreng, A.L.; Reynolds, T.C.; Smith, S.D.; Sklar, J. TAN-1, the human homolog of the Drosophila notch gene, is broken by chromosomal translocations in T lymphoblastic neoplasms. Cell 1991, 66, 649-661. [CrossRef]

38. Aster, J.C. Deregulated NOTCH signaling in acute T-cell lymphoblastic leukemia/lymphoma: New insights, questions, and opportunities. Int. J. Hematol. 2005, 82, 295-301. [CrossRef] [PubMed]

39. Aster, J.C.; Pear, W.S. Notch signaling in leukemia. Curr. Opin. Hematol. 2001, 8, 237-244. [CrossRef] [PubMed]

40. Aster, J.C.; Xu, L.; Karnell, F.G.; Patriub, V.; Pui, J.C.; Pear, W.S. Essential roles for ankyrin repeat and transactivation domains in induction of T-cell leukemia by Notch1. Mol. Cell. Biol. 2000, 20, 7505-7515. [CrossRef] [PubMed]

41. Robinson, D.R.; Kalyana-Sundaram, S.; Wu, Y.M.; Shankar, S.; Cao, X.; Ateeq, B.; Asangani, I.A.; Iyer, M.; Maher, C.A.; Grasso, C.S.; et al. Functionally recurrent rearrangements of the MAST kinase and Notch gene families in breast cancer. Nat. Med. 2011, 17, 1646-1651. [CrossRef] [PubMed]

42. Chinnaiyan, A.M.; Palanisamy, N. Chromosomal aberrations in solid tumors. Prog. Mol. Biol. Transl. Sci. 2010, 95, 55-94. [PubMed]

43. Wang, Z.; Zhang, Y.; Li, Y.; Banerjee, S.; Liao, J.; Sarkar, F.H. Down-regulation of Notch-1 contributes to cell growth inhibition and apoptosis in pancreatic cancer cells. Mol. Cancer Ther. 2006, 5, 483-493. [CrossRef] [PubMed]

44. Sancho, R.; Jandke, A.; Davis, H.; Diefenbacher, M.E.; Tomlinson, I.; Behrens, A. F-box and WD repeat domain-containing 7 regulates intestinal cell lineage commitment and is a haploinsufficient tumor suppressor. Gastroenterology 2010, 139, 929-941. [CrossRef] [PubMed]

45. Fazio, C.; Piazzi, G.; Vitaglione, P.; Fogliano, V.; Munarini, A.; Prossomariti, A.; Milazzo, M.; D’Angelo, L.; Napolitano, M.; Chieco, P.; et al. Inflammation increases NOTCH1 activity via MMP9 and is counteracted by Eicosapentaenoic Acid-free fatty acid in colon cancer cells. Sci. Rep. 2016, 6, 20670. [CrossRef] [PubMed]

46. Gupta-Rossi, N.; Le Bail, O.; Gonen, H.; Brou, C.; Logeat, F.; Six, E.; Ciechanover, A.; Israël, A. Functional interaction between SEL-10, an F-box protein, and the nuclear form of activated Notch1 receptor. J. Biol. Chem. 2001, 276, 34371-34378. [CrossRef] [PubMed]

47. Oberg, C.; Li, J.; Pauley, A.; Wolf, E.; Gurney, M.; Lendahl, U. The Notch intracellular domain is ubiquitinated and negatively regulated by the mammalian Sel-10 homolog. J. Biol. Chem. 2001, 276, 35847-35853. [CrossRef] [PubMed]

48. Wu, G.; Lyapina, S.; Das, I.; Li, J.; Gurney, M.; Pauley, A.; Chui, I.; Deshaies, R.J.; Kitajewski, J. SEL-10 is an inhibitor of notch signaling that targets notch for ubiquitin-mediated protein degradation. Mol. Cell. Biol. 2001, 21, 7403-7415. [CrossRef] [PubMed]

49. Allenspach, E.J.; Maillard, I.; Aster, J.C.; Pear, W.S. Notch signaling in cancer. Cancer Biol. Ther. 2002, 1, 466-476. [CrossRef] [PubMed]

50. Gao, C.; Liu, S.G.; Zhang, R.D.; Li, W.J.; Zhao, X.X.; Cui, L.; Wu, M.Y.; Zheng, H.Y.; Li, Z.G. NOTCH1 mutations are associated with favourable long-term prognosis in paediatric T-cell acute lymphoblastic leukaemia: A retrospective study of patients treated on BCH-2003 and CCLG-2008 protocol in China. Br. J. Haematol. 2014, 166, 221-228. [CrossRef] [PubMed]

51. Previs, R.A.; Coleman, R.L.; Harris, A.L.; Sood, A.K. Molecular pathways: Translational and therapeutic implications of the Notch signaling pathway in cancer. Clin. Cancer Res. 2015, 21, 955-961. [CrossRef] [PubMed]

52. Dickson, B.C.; Mulligan, A.M.; Zhang, H.; Lockwood, G.; O’Malley, F.P.; Egan, S.E.; Reedijk, M. High-level JAG1 mRNA and protein predict poor outcome in breast cancer. Mod. Pathol. 2007, 20, 685-693. [CrossRef] [PubMed] 
53. Reedijk, M.; Pinnaduwage, D.; Dickson, B.C.; Mulligan, A.M.; Zhang, H.; Bull, S.B.; O'Malley, F.P.; Egan, S.E.; Andrulis, I.L. JAG1 expression is associated with a basal phenotype and recurrence in lymph node-negative breast cancer. Breast Cancer Res. Treat. 2008, 111, 439-448. [CrossRef] [PubMed]

54. Haines, N.; Irvine, K.D. Glycosylation regulates Notch signalling. Nat. Rev. Mol. Cell Biol. 2003, 4, 786-797. [CrossRef] [PubMed]

55. Fryer, C.J.; White, J.B.; Jones, K.A. Mastermind recruits CycC:CDK8 to phosphorylate the Notch ICD and coordinate activation with turnover. Mol. Cell 2004, 16, 509-520. [CrossRef] [PubMed]

56. Ntziachristos, P.; Lim, J.S.; Sage, J.; Aifantis, I. From fly wings to targeted cancer therapies: A centennial for notch signaling. Cancer Cell 2014, 25, 318-334. [CrossRef] [PubMed]

57. Ferlay, J.; Soerjomataram, I.; Dikshit, R.; Eser, S.; Mathers, C.; Rebelo, M.; Parkin, D.M.; Forman, D.; Bray, F. Cancer incidence and mortality worldwide: Sources, methods and major patterns in GLOBOCAN 2012. Int. J. Cancer 2015, 136, E359-E386. [CrossRef] [PubMed]

58. Kumar, M.; Kumar, R.; Hissar, S.S.; Saraswat, M.K.; Sharma, B.C.; Sakhuja, P.; Sarin, S.K. Risk factors analysis for hepatocellular carcinoma in patients with and without cirrhosis: A case-control study of 213 hepatocellular carcinoma patients from India. J. Gastroenterol. Hepatol. 2007, 22, 1104-1111. [CrossRef] [PubMed]

59. Schlaeger, C.; Longerich, T.; Schiller, C.; Bewerunge, P.; Mehrabi, A.; Toedt, G.; Kleeff, J.; Ehemann, V.; Eils, R.; Lichter, P.; et al. Etiology-dependent molecular mechanisms in human hepatocarcinogenesis. Hepatology 2008, 47, 511-520. [CrossRef] [PubMed]

60. Lopez, P.M.; Villanueva, A.; Llovet, J.M. Systematic review: Evidence-based management of hepatocellular carcinoma-An updated analysis of randomized controlled trials. Aliment. Pharmacol. Ther. 2006, 23, 1535-1547. [CrossRef] [PubMed]

61. Kemp, W.; Pianko, S.; Nguyen, S.; Bailey, M.J.; Roberts, S.K. Survival in hepatocellular carcinoma: Impact of screening and etiology of liver disease. J. Gastroenterol. Hepatol. 2005, 20, 873-881. [CrossRef] [PubMed]

62. Lim, S.O.; Kim, H.S.; Quan, X.; Ahn, S.M.; Kim, H.; Hsieh, D.; Seong, J.K.; Jung, G. Notch1 binds and induces degradation of Snail in hepatocellular carcinoma. BMC Biol. 2011, 9, 83. [CrossRef] [PubMed]

63. Tryndyak, V.P.; Ross, S.A.; Beland, F.A.; Pogribny, I.P. Down-regulation of the microRNAs miR-34a, miR-127, and $\mathrm{miR}-200 \mathrm{~b}$ in rat liver during hepatocarcinogenesis induced by a methyl-deficient diet. Mol. Carcinog. 2009, 48, 479-487. [CrossRef] [PubMed]

64. Villanueva, A.; Alsinet, C.; Yanger, K.; Hoshida, Y.; Zong, Y.; Toffanin, S.; Rodriguez-Carunchio, L.; Solé, M.; Thung, S.; Stanger, B.Z.; et al. Notch signaling is activated in human hepatocellular carcinoma and induces tumor formation in mice. Gastroenterology 2012, 143, 1660-1669.e7. [CrossRef] [PubMed]

65. Qi, R.; An, H.; Yu, Y.; Zhang, M.; Liu, S.; Xu, H.; Guo, Z.; Cheng, T.; Cao, X. Notch1 signaling inhibits growth of human hepatocellular carcinoma through induction of cell cycle arrest and apoptosis. Cancer Res. 2003, 63, 8323-8329. [PubMed]

66. Hayashi, Y.; Osanai, M.; Lee, G.H. Notch2 signaling confers immature morphology and aggressiveness in human hepatocellular carcinoma cells. Oncol. Rep. 2015, 34, 1650-1658. [CrossRef] [PubMed]

67. Wu, W.R.; Zhang, R.; Shi, X.D.; Yi, C.; Xu, L.B.; Liu, C. Notch2 is a crucial regulator of self-renewal and tumorigenicity in human hepatocellular carcinoma cells. Oncol. Rep. 2016, 36, 181-188. [CrossRef] [PubMed]

68. Ahn, S.; Hyeon, J.; Park, C.K. Notch1 and Notch4 are markers for poor prognosis of hepatocellular carcinoma. Hepatobiliary Pancreat Dis. Int. 2013, 12, 286-294. [CrossRef]

69. Gramantieri, L.; Giovannini, C.; Lanzi, A.; Chieco, P.; Ravaioli, M.; Venturi, A.; Grazi, G.L.; Bolondi, L. Aberrant Notch3 and Notch4 expression in human hepatocellular carcinoma. Liver Int. 2007, 27, 997-1007. [CrossRef] [PubMed]

70. Dill, M.T.; Tornillo, L.; Fritzius, T.; Terracciano, L.; Semela, D.; Bettler, B.; Heim, M.H.; Tchorz, J.S. Constitutive Notch2 signaling induces hepatic tumors in mice. Hepatology 2013, 57, 1607-1619. [CrossRef] [PubMed]

71. Ortica, S.; Tarantino, N.; Aulner, N.; Israel, A.; Gupta-Rossi, N. The 4 Notch receptors play distinct and antagonistic roles in the proliferation and hepatocytic differentiation of liver progenitors. FASEB J. 2014, 28, 603-614. [CrossRef] [PubMed]

72. Wang, T.; You, N.; Tao, K.; Wang, X.; Zhao, G.; Xia, N.; Li, N.; Tang, L.; Liu, W.; Dou, K. Notch is the key factor in the process of fetal liver stem/progenitor cells differentiation into hepatocytes. Dev. Growth Differ. 2012, 54, 605-617. [CrossRef] [PubMed] 
73. Flynn, D.M.; Nijjar, S.; Hubscher, S.G.; de Goyet Jde, V.; Kelly, D.A.; Strain, A.J.; Crosby, H.A. The role of Notch receptor expression in bile duct development and disease. J. Pathol. 2004, 204, 55-64. [CrossRef] [PubMed]

74. Nijjar, S.S.; Crosby, H.A.; Wallace, L.; Hubscher, S.G.; Strain, A.J. Notch receptor expression in adult human liver: A possible role in bile duct formation and hepatic neovascularization. Hepatology 2001, 34, 1184-1192. [CrossRef] [PubMed]

75. Hu, L.; Xue, F.; Shao, M.; Deng, A.; Wei, G. Aberrant expression of Notch3 predicts poor survival for hepatocellular carcinomas. Biosci. Trends 2013, 7, 152-156. [PubMed]

76. Gao, J.; Song, Z.; Chen, Y.; Xia, L.; Wang, J.; Fan, R.; Du, R.; Zhang, F.; Hong, L.; Song, J.; et al. Deregulated expression of Notch receptors in human hepatocellular carcinoma. Dig. Liver Dis. 2008, 40, 114-121. [CrossRef] [PubMed]

77. McAuliffe, S.M.; Morgan, S.L.; Wyant, G.A.; Tran, L.T.; Muto, K.W.; Chen, Y.S.; Chin, K.T.; Partridge, J.C.; Poole, B.B.; Cheng, K.H.; et al. Targeting Notch, a key pathway for ovarian cancer stem cells, sensitizes tumors to platinum therapy. Proc. Natl. Acad. Sci. USA 2012, 109, E2939-E2948. [CrossRef] [PubMed]

78. Wang, J.; Wakeman, T.P.; Lathia, J.D.; Hjelmeland, A.B.; Wang, X.F.; White, R.R.; Rich, J.N.; Sullenger, B.A. Notch promotes radioresistance of glioma stem cells. Stem Cells 2010, 28, 17-28. [CrossRef] [PubMed]

79. Giovannini, C.; Gramantieri, L.; Chieco, P.; Minguzzi, M.; Lago, F.; Pianetti, S.; Ramazzotti, E.; Marcu, K.B.; Bolondi, L. Selective ablation of Notch3 in HCC enhances doxorubicin's death promoting effect by a p53 dependent mechanism. J. Hepatol. 2009, 50, 969-979. [CrossRef] [PubMed]

80. Chen, S.M.; Liu, J.P.; Zhou, J.X.; Chen, C.; Deng, Y.Q.; Wang, Y.; Tao, Z.Z. Suppression of the notch signaling pathway by $\gamma$-secretase inhibitor GSI inhibits human nasopharyngeal carcinoma cell proliferation. Cancer Lett. 2011, 306, 76-84. [CrossRef] [PubMed]

81. Kondratyev, M.; Kreso, A.; Hallett, R.M.; Girgis-Gabardo, A.; Barcelon, M.E.; Ilieva, D.; Ware, C.; Majumder, P.K.; Hassell, J.A. $\gamma$-Secretase inhibitors target tumor-initiating cells in a mouse model of ERBB2 breast cancer. Oncogene 2012, 31, 93-103. [CrossRef] [PubMed]

82. Luistro, L.; He, W.; Smith, M.; Packman, K.; Vilenchik, M.; Carvajal, D.; Roberts, J.; Cai, J.; Berkofsky-Fessler, W.; Hilton, H.; et al. Preclinical profile of a potent $\gamma$-secretase inhibitor targeting notch signaling with in vivo efficacy and pharmacodynamic properties. Cancer Res. 2009, 69, 7672-7680. [CrossRef] [PubMed]

83. Zhang, C.C.; Pavlicek, A.; Zhang, Q.; Lira, M.E.; Painter, C.L.; Yan, Z.; Zheng, X.; Lee, N.V.; Ozeck, M.; Qiu, M.; et al. Biomarker and pharmacologic evaluation of the $\gamma$-secretase inhibitor PF-03084014 in breast cancer models. Clin. Cancer Res. 2012, 18, 5008-5019. [CrossRef] [PubMed]

84. Yabuuchi, S.; Pai, S.G.; Campbell, N.R.; de Wilde, R.F.; de Oliveira, E.; Korangath, P.; Streppel, M.M.; Rasheed, Z.A.; Hidalgo, M.; Maitra, A.; et al. Notch signaling pathway targeted therapy suppresses tumor progression and metastatic spread in pancreatic cancer. Cancer Lett. 2013, 335, 41-51. [CrossRef] [PubMed]

85. Arcaroli, J.J.; Powell, R.W.; Varella-Garcia, M.; McManus, M.; Tan, A.C.; Quackenbush, K.S.; Pitts, T.M.; Gao, D.; Spreafico, A.; Dasari, A.; et al. ALDH+ tumor-initiating cells exhibiting gain in NOTCH1 gene copy number have enhanced regrowth sensitivity to a $\gamma$-secretase inhibitor and irinotecan in colorectal cancer. Mol. Oncol. 2012, 6, 370-381. [CrossRef] [PubMed]

86. Beel, A.J.; Sanders, C.R. Substrate specificity of $\gamma$-secretase and other intramembrane proteases. Cell. Mol. Life Sci. 2008, 65, 1311-1334. [CrossRef] [PubMed]

87. Wong, G.T.; Manfra, D.; Poulet, F.M.; Zhang, Q.; Josien, H.; Bara, T.; Engstrom, L.; Pinzon-Ortiz, M.; Fine, J.S.; Lee, H.J.; et al. Chronic treatment with the $\gamma$-secretase inhibitor LY-411,575 inhibits $\beta$-amyloid peptide production and alters lymphopoiesis and intestinal cell differentiation. J. Biol. Chem. 2004, 279, 12876-12882. [CrossRef] [PubMed]

88. Giovannini, C.; Gramantieri, L.; Minguzzi, M.; Fornari, F.; Chieco, P.; Grazi, G.L.; Bolondi, L. CDKN1C/P57 is regulated by the Notch target gene Hes1 and induces senescence in human hepatocellular carcinoma. Am. J. Pathol. 2012, 181, 413-422. [CrossRef] [PubMed]

89. Edington, K.G.; Loughran, O.P.; Berry, I.J.; Parkinson, E.K. Cellular immortality: A late event in the progression of human squamous cell carcinoma of the head and neck associated with p53 alteration and a high frequency of allele loss. Mol. Carcinog. 1995, 13, 254-265. [CrossRef] [PubMed]

90. Paraskeva, C.; Finerty, S.; Powell, S. Immortalization of a human colorectal adenoma cell line by continuous in vitro passage: Possible involvement of chromosome 1 in tumour progression. Int. J. Cancer 1988, 41, 908-912. [CrossRef] [PubMed] 
91. Wynford-Thomas, D. Origin and progression of thyroid epithelial tumours: Cellular and molecular mechanisms. Horm. Res. 1997, 47, 145-157. [CrossRef] [PubMed]

92. Roninson, I.B. Tumor cell senescence in cancer treatment. Cancer Res. 2003, 63, 2705-2715. [PubMed]

93. Guo, S.; Liu, M.; Gonzalez-Perez, R.R. Role of Notch and its oncogenic signaling crosstalk in breast cancer. Biochim. Biophys. Acta 2011, 1815, 197-213. [CrossRef] [PubMed]

94. Ristorcelli, E.; Lombardo, D. Targeting Notch signaling in pancreatic cancer. Expert Opin. Ther. Targets 2010, 14, 541-552. [CrossRef] [PubMed]

95. Nakamura, T.; Tsuchiya, K.; Watanabe, M. Crosstalk between Wnt and Notch signaling in intestinal epithelial cell fate decision. J. Gastroenterol. 2007, 42, 705-710. [CrossRef] [PubMed]

96. Li, J.L.; Harris, A.L. Crosstalk of VEGF and Notch pathways in tumour angiogenesis: Therapeutic implications. Front. Biosci. (Landmark Ed.) 2009, 14, 3094-3110. [CrossRef] [PubMed]

97. Yeung, T.M.; Gandhi, S.C.; Bodmer, W.F. Hypoxia and lineage specification of cell line-derived colorectal cancer stem cells. Proc. Natl. Acad. Sci. USA 2011, 108, 4382-4387. [CrossRef] [PubMed]

98. Ma, J.; Meng, Y.; Kwiatkowski, D.J.; Chen, X.; Peng, H.; Sun, Q.; Zha, X.; Wang, F.; Wang, Y.; Jing, Y.; et al. Mammalian target of rapamycin regulates murine and human cell differentiation through STAT3/p63/Jagged/Notch cascade. J. Clin. Investig. 2010, 120, 103-114. [CrossRef] [PubMed]

99. Chan, S.M.; Weng, A.P.; Tibshirani, R.; Aster, J.C.; Utz, P.J. Notch signals positively regulate activity of the mTOR pathway in T-cell acute lymphoblastic leukemia. Blood 2007, 110, 278-286. [CrossRef] [PubMed]

100. Dotto, G.P. Crosstalk of Notch with p53 and p63 in cancer growth control. Nat. Rev. Cancer 2009, 9, 587-595. [CrossRef] [PubMed]

101. Vogelstein, B.; Lane, D.; Levine, A.J. Surfing the p53 network. Nature 2000, 408, 307-310. [CrossRef] [PubMed]

102. Hollstein, M.; Sidransky, D.; Vogelstein, B.; Harris, C.C. p53 mutations in human cancers. Science 1991, 253, 49-53. [CrossRef] [PubMed]

103. Beverly, L.J.; Felsher, D.W.; Capobianco, A.J. Suppression of p53 by Notch in lymphomagenesis: Implications for initiation and regression. Cancer Res. 2005, 65, 7159-7168. [CrossRef] [PubMed]

104. Hsu, K.W.; Fang, W.L.; Huang, K.H.; Huang, T.T.; Lee, H.C.; Hsieh, R.H.; Chi, C.W.; Yeh, T.S. Notch1 pathway-mediated microRNA-151-5p promotes gastric cancer progression. Oncotarget 2016, 7, 38036-38051. [CrossRef] [PubMed]

105. Mungamuri, S.K.; Yang, X.; Thor, A.D.; Somasundaram, K. Survival signaling by Notch1: Mammalian target of rapamycin (mTOR)-dependent inhibition of p53. Cancer Res. 2006, 66, 4715-4724. [CrossRef] [PubMed]

106. Giovannini, C.; Minguzzi, M.; Baglioni, M.; Fornari, F.; Giannone, F.; Ravaioli, M.; Cescon, M.; Chieco, P.; Bolondi, L.; Gramantieri, L. Suppression of 533 by Notch3 is mediated by Cyclin G1 and sustained by MDM2 and miR-221 axis in hepatocellular carcinoma. Oncotarget 2014, 5, 10607-10620. [CrossRef] [PubMed]

107. Wang, C.; Qi, R.; Li, N.; Wang, Z.; An, H.; Zhang, Q.; Yu, Y.; Cao, X. Notch1 signaling sensitizes tumor necrosis factor-related apoptosis-inducing ligand-induced apoptosis in human hepatocellular carcinoma cells by inhibiting Akt/Hdm2-mediated p53 degradation and up-regulating p53-dependent DR5 expression. J. Biol. Chem. 2009, 284, 16183-16190. [CrossRef] [PubMed]

108. Boggs, K.; Henderson, B.; Reisman, D. RBP-Jk binds to and represses transcription of the p53 tumor suppressor gene. Cell Biol. Int. 2009, 33, 318-324. [CrossRef] [PubMed]

109. Colaluca, I.N.; Tosoni, D.; Nuciforo, P.; Senic-Matuglia, F.; Galimberti, V.; Viale, G.; Pece, S.; Di Fiore, P.P. NUMB controls p53 tumour suppressor activity. Nature 2008, 451, 76-80. [CrossRef] [PubMed]

110. Carter, S.; Vousden, K.H. A role for Numb in p53 stabilization. Genome Biol. 2008, 9, 221. [CrossRef] [PubMed]

111. Dotto, G.P. Notch tumor suppressor function. Oncogene 2008, 27, 5115-5123. [CrossRef] [PubMed]

112. Yugawa, T.; Handa, K.; Narisawa-Saito, M.; Ohno, S.; Fujita, M.; Kiyono, T. Regulation of Notch1 gene expression by 53 in epithelial cells. Mol. Cell. Biol. 2007, 27, 3732-3742. [CrossRef] [PubMed]

113. Wei, C.L.; Wu, Q.; Vega, V.B.; Chiu, K.P.; Ng, P.; Zhang, T.; Shahab, A.; Yong, H.C.; Fu, Y.; Weng, Z.; et al. A global map of p53 transcription-factor binding sites in the human genome. Cell 2006, 124, 207-219. [CrossRef] [PubMed]

(C) 2016 by the authors; licensee MDPI, Basel, Switzerland. This article is an open access article distributed under the terms and conditions of the Creative Commons Attribution (CC-BY) license (http://creativecommons.org/licenses/by/4.0/). 